\title{
anu \\ Cytotoxicity and Effects on the Synapsis Induced by Pure Cylindrospermopsin in an E17 Embryonic Murine Primary Neuronal Culture in a Concentration- and Time-Dependent Manner
}

\author{
María G. Hinojosa ${ }^{1}$, Ana I. Prieto ${ }^{1, *(\mathbb{D}, \text {, Clara Muñoz-Castro }}{ }^{2,3,4}$, María V. Sánchez-Mico ${ }^{2,3,4} \mathbb{D}_{\text {, Javier Vitorica }}{ }^{2,3,4}$ \\ Ana M. Cameán ${ }^{1}$ (D) and Ángeles Jos ${ }^{1}$ (D) \\ 1 Area of Toxicology, Faculty of Pharmacy, University of Sevilla, C/Profesor García González 2, 41012 Sevilla, \\ Spain; mhinojosa1@us.es (M.G.H.); camean@us.es (A.M.C.); angelesjos@us.es (Á.J.) \\ 2 Department of Biochemistry and Molecular Biology, Faculty of Pharmacy, University of Sevilla, 41012 Sevilla, \\ Spain; cmunozcastro@mgh.harvard.edu (C.M.-C.); marsanmic@gmail.com (M.V.S.-M.); vitorica@us.es (J.V.) \\ 3 Biomedicine Institute of Sevilla (IBiS), Universitary Hospital Virgen del Rocío/CSIC/University of Sevilla, \\ 41013 Sevilla, Spain \\ 4 Biomedical Research Center in Network on Neurodegenerative Diseases (CIBERNED), 28031 Madrid, Spain \\ * Correspondence: anaprieto@us.es
}

Citation: Hinojosa, M.G.; Prieto, A.I.; Muñoz-Castro, C.; Sánchez-Mico, M.V.; Vitorica, J.; Cameán, A.M.; Jos, Á. Cytotoxicity and Effects on the Synapsis Induced by Pure Cylindrospermopsin in an E17 Embryonic Murine Primary Neuronal Culture in a Concentrationand Time-Dependent Manner. Toxins 2022, 14, 175. https://doi.org/ $10.3390 /$ toxins 14030175

Received: 25 January 2022 Accepted: 24 February 2022 Published: 26 February 2022

Publisher's Note: MDPI stays neutral with regard to jurisdictional claims in published maps and institutional affiliations.

Copyright: (C) 2022 by the authors. Licensee MDPI, Basel, Switzerland. This article is an open access article distributed under the terms and conditions of the Creative Commons Attribution (CC BY) license (https:// creativecommons.org/licenses/by/ $4.0 /)$.

\begin{abstract}
Cylindrospermopsin (CYN) is a cyanotoxin whose incidence has been increasing in the last decades. Due to its capacity to exert damage at different levels of the organism, it is considered a cytotoxin. Although the main target organ is the liver, recent studies indicate that CYN has potential toxic effects on the nervous system, both in vitro and in vivo. Thus, the aim of the present work was to study the effects of this cyanotoxin on neuronal viability and synaptic integrity in murine primary cultures of neurons exposed to environmentally relevant concentrations $(0-1 \mu \mathrm{g} / \mathrm{mL}$ CYN) for 12,24 , and $48 \mathrm{~h}$. The results demonstrate a concentration- and time-dependent decrease in cell viability; no cytotoxicity was detected after exposure to the cyanotoxin for $12 \mathrm{~h}$, while all of the concentrations assayed decreased this parameter after $48 \mathrm{~h}$. Furthermore, CYN was also demonstrated to exert damage at the synaptic level in a murine primary neuronal culture in a concentration- and timedependent manner. These data highlight the importance of studying the neurotoxic properties of this cyanotoxin in different experimental models.
\end{abstract}

Keywords: cylindrospermopsin; cytotoxicity; primary neuronal cultures; neurotoxicity; synapsis

Key Contribution: Cylindrospermopsin decreases viability in murine primary cultures of neurons. Cylindrospermopsin decreases the synaptic number in neuronal murine primary cultures. Cylindrospermopsin affects neuronal murine primary cultures in a concentration- and time-dependent manner.

\section{Introduction}

Cylindrospermopsin (CYN) is a secondary metabolite produced by several species of cyanobacteria, such as Cylindrospermopsis raciborskii, Aphanizomenon ovalisporum, Raphidiopsis curvata, Chrysosporum ovalisporum, Lyngbia wollei, Anabaena bergii, Umezakia natans, Oscillatoria sp., etc. [1,2]. Structurally, this cyanotoxin consists of a tricyclic guanidine moiety with a hydroxymethyl uracil [3]. Due to its zwitterionic nature and its low molecular weight, this molecule is highly soluble in water and stable in many environmental conditions $[4,5]$. These factors, together with the cosmopolitan distribution of producing species, have led to an increase in its incidence in the last decades [6]. In this context, Yang et al. [7] reported the presence of CYN in water bodies on six continents, and it was found to be quite common in waters in Europe, Asia, Oceania, and North America and 
less documented in South America and Africa. Of the tested samples, the highest value reported was $1050 \mu \mathrm{g} / \mathrm{L} \mathrm{CYN} \mathrm{in} \mathrm{an} \mathrm{Australian} \mathrm{water} \mathrm{supply} \mathrm{[7].}$

Furthermore, cyanotoxins have demonstrated their capacity to bioaccumulate in several organisms in different parts of the food chain [8,9], such as mollusks [10], fish [11], toads, and plants [5,12]. Thus, their main route of exposure would be the oral route through contaminated water or food intake. However, dermal, inhalation, and parenteral exposures are also possible. The most famous case of human intoxication caused by CYN was an outbreak of hepatic enteritis on Palm Island, Queensland, Australia, where over 150 people presented symptoms of headache, anorexia, vomiting, hepatomegaly, bloody diarrhea, and dehydration $[13,14]$. All of them reported water intake from a reservoir that contained a bloom of a CYN-producing strain of $R$. raciborskii [13]. Furthermore, in Brazil, CYN was also detected in Caruaru syndrome, caused by the presence of a different cyanotoxin, microcystin, in the water from a hemodialysis clinic, although no CYN quantification was performed, so it was not possible to evaluate its contribution to the effects observed $[6,15]$. Cylindrospermopsin is classified as a cytotoxin and is able to exert toxicity in many different cell lines, such as HepG2, Caco-2, and CHO, among others [7,16-18]. Moreover, many cases of animal intoxication have been reported, most of them leading to death, demonstrating CYN bioaccumulation mainly in the liver, although other organs were also affected [7]. In this sense, this cyanotoxin has been demonstrated to exert damage in different organs, such as the lungs, heart, kidneys, thymus, spleen, and nervous system $[7,19,20]$.

Different in vivo laboratory studies have shown that CYN produces oxidative stress and histopathological lesions in the liver, kidney, heart, intestines, and gills in tilapia that were subchronically exposed (14 days) by immersion to lyophilized Aphanizomenon ovalisporum cells at environmentally relevant concentrations [21]. Moreover, CYN induced significant inhibition of AChE activity and increased LPO levels, as well as relevant histopathological alterations in the brain of fish subchronically exposed to the toxin [22]. Thus, CYN has been demonstrated to be able to cross the blood-brain barrier, as its presence has been detected in the brain of at least three different fish species [22-24]. In mice that were subchronically orally exposed to purified CYN $(75-300 \mu \mathrm{g} / \mathrm{kg} / \mathrm{d})$ for 90 days, toxicity was noted at all dose levels tested [25]. Thus, Chernoff et al. [25] observed elevated organ-to-body weight ratios of the liver and kidney, important histopathological lesions (hepatocellular hypertrophy, cord disruption in the liver, and renal cellular hypertrophy), and alterations of some biochemical parameters. In contrast, recently, Diez-Quijada et al. [26] carried out a study in rats with repeated oral exposure to pure CYN (up to $75.0 \mathrm{\mu g} / \mathrm{kg} \mathrm{bw}$ ) for 28 days, and they did not find statistically significant differences in hematological and biochemical parameters.

The main mechanism of action of CYN is protein synthesis inhibition, including the synthesis of the tripeptide glutathione (GSH), which leads to oxidative stress, which, in turn, leads to increased lipid peroxidation, DNA damage, and apoptosis $[7,20,24,27-30]$. However, the neurotoxic effects of this cyanotoxin have been poorly studied so far, with previous reports mainly demonstrating apoptosis, oxidative stress, and alteration of acetylcholinesterase activity, but no studies have focused on neuronal function [19,31]. Thus, the objective of the present work was to assess the neurotoxic effect of CYN on cell viability and synaptic density in murine primary cultured neurons in order to predict a possible mechanism involved in this neurotoxicity.

\section{Results}

\subsection{Cytotoxicity of CYN in Murine Primary Neuronal Culture}

Neuronal viability was measured by immunocytochemistry using the markers NeuN and microtubule-associated protein 2 (MAP-2). NeuN is a specific protein from postmitotic neurons used to assess neuronal differentiation [32]. In addition, MAP-2, present in postmitotic neurons, is a structural protein necessary to maintain neuroarchitecture and plays a role in responses to growth factors, neurotransmitters, synaptic activity, and neurotoxins $[33,34]$. Thus, both markers were used not only to study viability but also to confirm 
that the cells under study were specifically neurons. For this purpose, primary neuronal cultures were exposed to different concentrations of CYN $(0.25-1 \mu \mathrm{g} / \mathrm{mL})$ for different durations $(12,24$, and $48 \mathrm{~h})$, and the number of neurons was quantified by MAP2 and NeuN immunocytochemistry. As shown in Figure 1, a significant decrease in neuronal viability was observed after $48 \mathrm{~h}$ of exposure for all concentrations of CYN assayed and after $24 \mathrm{~h}$ of exposure only for the highest concentration $(1 \mu \mathrm{g} / \mathrm{mL}$ CYN). The treatment of neurons without the B27 supplement served as a positive control of neuronal death because it is an essential supplement for the survival of primary neurons in vitro. Ultimately, important differences were observed in the cytotoxicity of CYN in murine primary neurons in a timeand concentration-dependent manner (Figure 2).

$12 \mathrm{~h}$
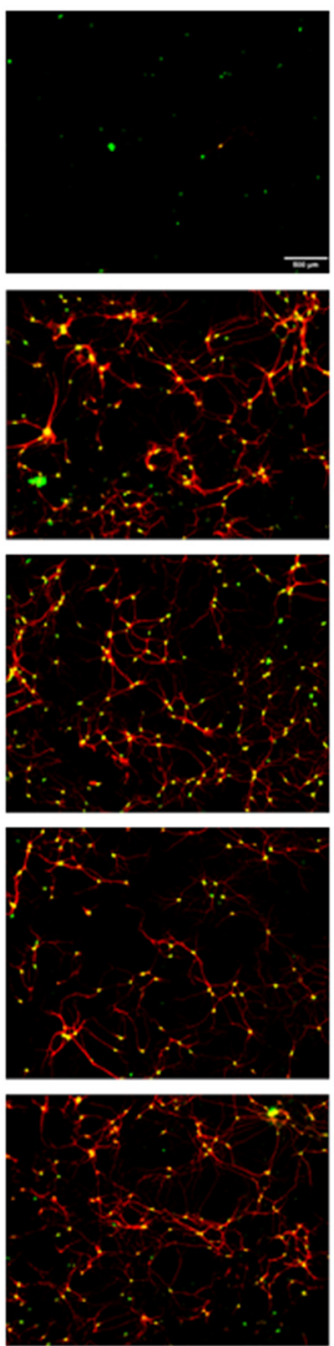

$24 \mathrm{~h}$
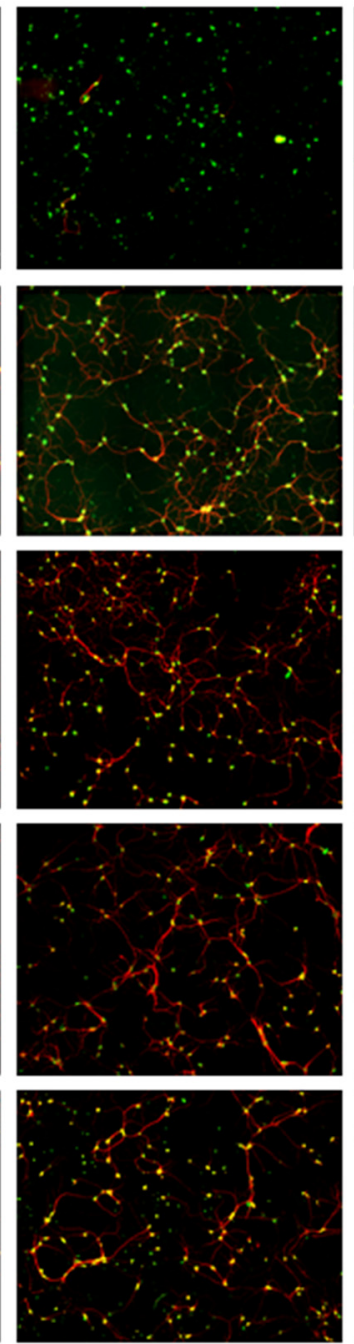

$48 \mathrm{~h}$
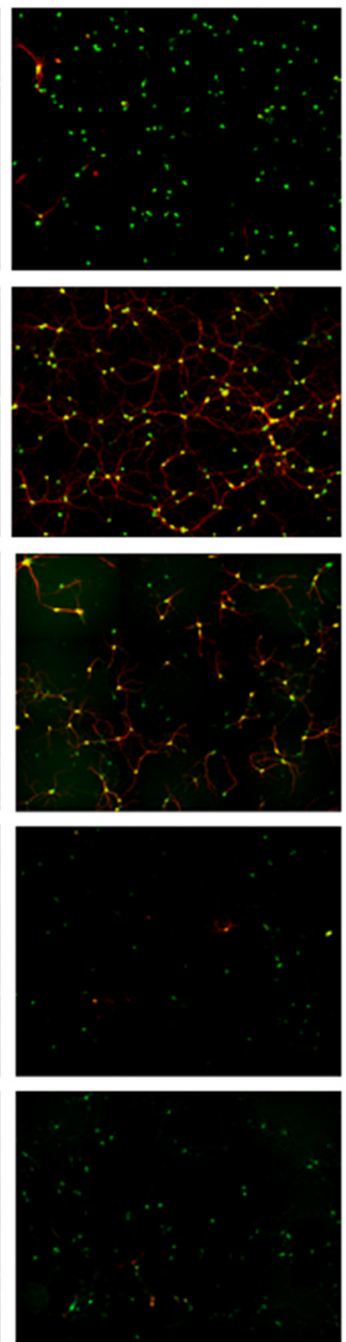

Positive

Control C+

Negative

Control C-

$0.25 \mu \mathrm{g} / \mathrm{mL}$

$0.5 \mu \mathrm{g} / \mathrm{mL}$ $\mathrm{CYN}$

$1 \mu \mathrm{g} / \mathrm{mL} \mathrm{CYN}$

Figure 1. Images of murine primary neurons from E17 embryonic mice after exposure to $0.25,0.5$, and $1 \mu \mathrm{g} / \mathrm{mL}$ for 12, 24 and $48 \mathrm{~h}$ taken with the Apotome Zeiss epifluorescence microscope, where NeuN and MAP2 are shown in green and red, respectively. Control C-: neurobasal medium with B27 supplements were used as a negative control. Control $C+$ : neurobasal medium without B27 were used as a positive control of reduced neuronal viability. Scale bars, $500 \mu \mathrm{m}$. 


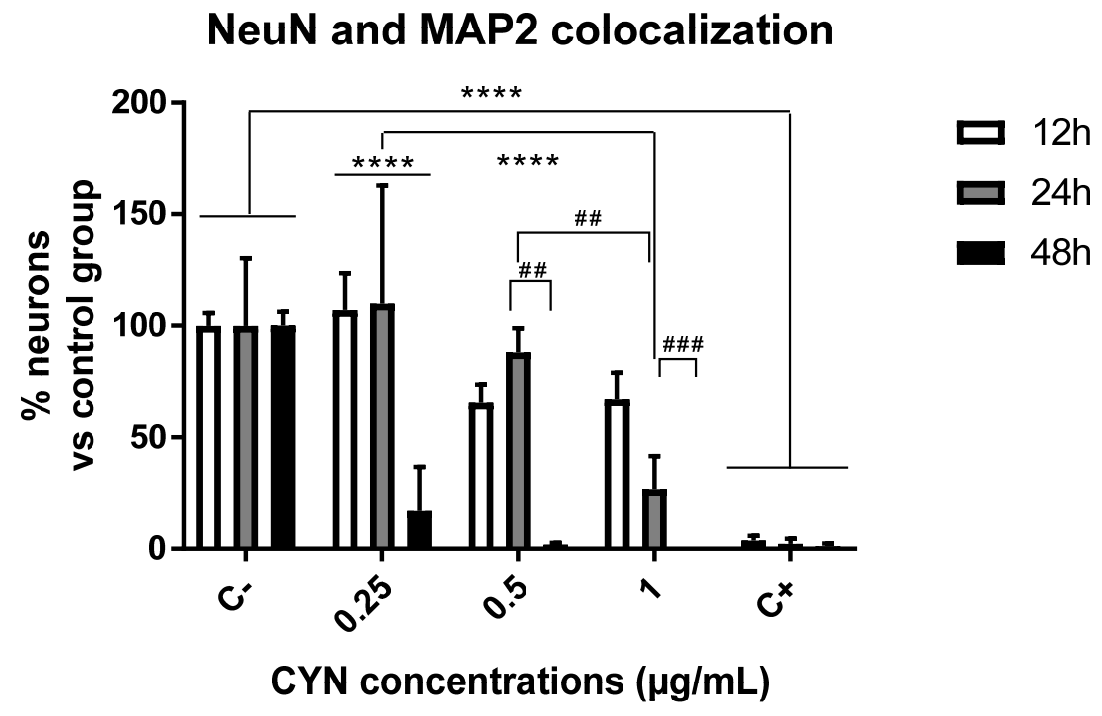

Figure 2. Effect of $0-1 \mu \mathrm{g} / \mathrm{mL}$ CYN on neuronal viability quantified by NeuN and MAP-2 colocalization immunocytochemistry in E17 primary cultures exposed to the toxin for 12, 24, and $48 \mathrm{~h}(n=4)$. **** $p<0.0001$, compared to their respective control group; \#\# $p<0.005$, \#\#\# $p<0.0005$, compared to the same concentration of exposure. Control C-: neurobasal medium with B27 supplements were used as a negative control. Control $\mathrm{C}+$ : neurobasal medium without B27 were used as a positive control of reduced neuronal viability.

\subsection{Effect of CYN on the Number of Synapses in Murine Primary Neuronal Culture}

The number of synapses was measured by studying synaptophysin 1 and PSD95 colocalization. Synaptophysin is an integral membrane protein of small synaptic vesicles and is involved in the exocytosis of stored neurotransmitters [35]. In addition, PSD95 is one of the most abundant proteins in postsynaptic neurons and is involved in synaptic maturation [36]. The colocalization of both proteins allows the detection and quantification of synapses. In order to study the effect of CYN on synaptic integrity, primary neuronal cultures were exposed to different concentrations of this toxin for different durations, and the colocalization of synaptophysin and PSD95 was used to quantify the number of synaptic connections. The results showed that the highest decrease in synaptic number occurred at a concentration of $1 \mu \mathrm{g} / \mathrm{mL}$ CYN in murine primary neurons. In fact, significant concentration-dependent differences $(0.25$ vs. 1$)$ in this neuronal function were observed in cells exposed to the toxin for $12 \mathrm{~h}$ (Figures 3 and 4). The treatment of neurons without the B27 supplement induced the loss or de-colocalization of these two synaptic markers, so it served as a positive control of reduced synaptic integrity. 

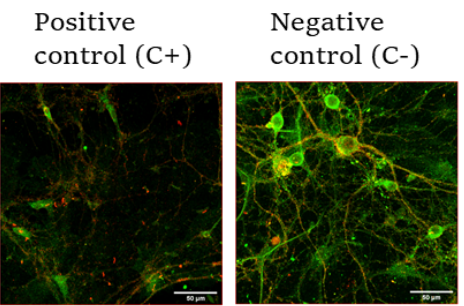

$0.25 \mu \mathrm{g} / \mathrm{mL}$

$0.5 \mu \mathrm{g} / \mathrm{mL}$

$1 \mu \mathrm{g} / \mathrm{mL}$
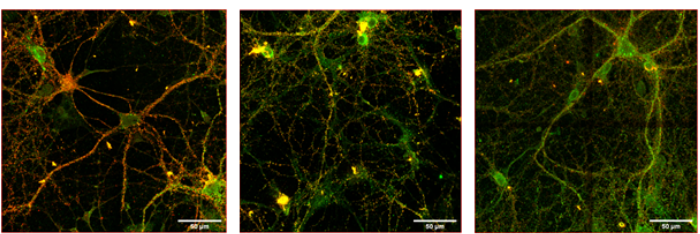

$12 \mathrm{~h}$
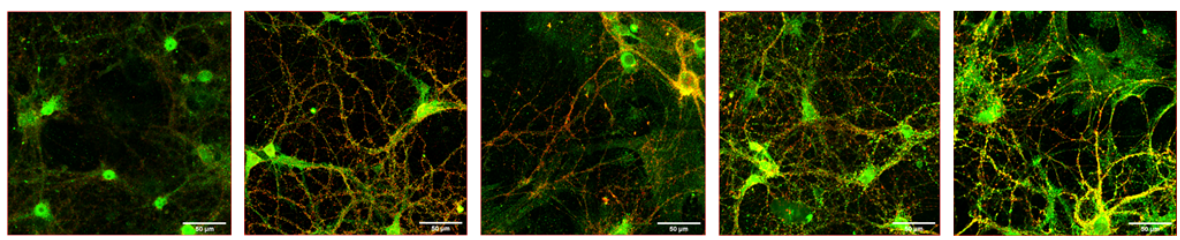

$24 \mathrm{~h}$

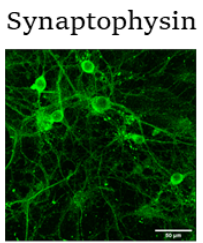

PSD95

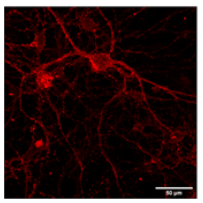

Merge

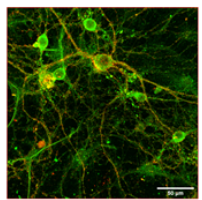

Figure 3. Representative images of murine primary neurons (synaptophysin, green; PSD95, red) from E17 embryonic mice after exposure to $0.25,0.5$, and $1 \mu \mathrm{g} / \mathrm{mL}$ for 12 and $24 \mathrm{~h}$ taken with the ZEISS LSM 710 confocal microscope. Control C-: neurobasal medium with B27 supplements were used as a negative control. Control C+: neurobasal medium without B27 were used as a positive control of reduced neuronal viability. Scale bars, $50 \mu \mathrm{m}$. Merging of pre- and postsynaptic markers.

\section{Synaptophysin and PSD95 colocalization}

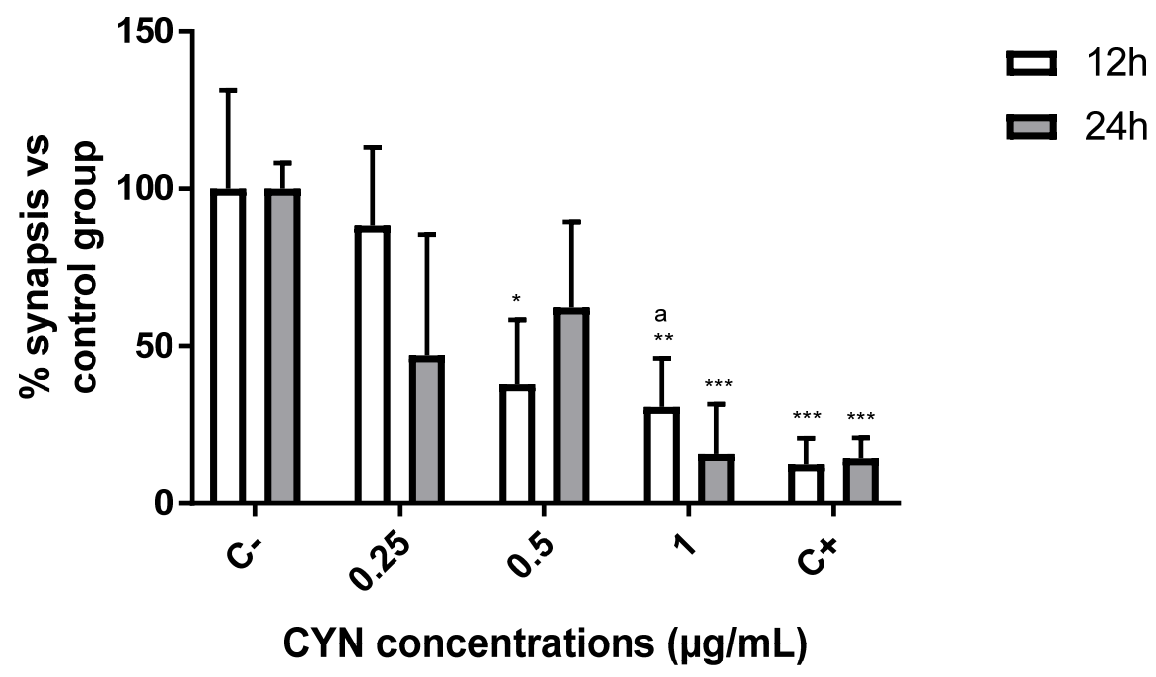

Figure 4. Effect of $0-1 \mu \mathrm{g} / \mathrm{mL}$ CYN on synaptic integrity measured by synaptophysin and PSD95 colocalization in E17 primary neuronal cultures for 12 and $24 \mathrm{~h}(n=4){ }^{*} p<0.05,{ }^{* *} p<0.005$, *** $p<0.0005$, compared to their respective negative control. a $p<0.05$, compared to $0.25 \mu \mathrm{g} / \mathrm{mL}$ at the indicated time of exposure. Control C-: neurobasal medium with B27 supplements were used as a negative control. Control C+: neurobasal medium without B27 were used as a positive control of reduced neuronal viability.

\section{Discussion}

Neurodegenerative diseases are a leading cause of death and affect a huge number of people worldwide [37]. Moreover, it is known that some toxicants may cause or/and hasten neuronal senescence [38]. Currently, studies concerning the neurotoxic effects of 
CYN are very scarce. CYN is known to be cytotoxic, and this has been proven in different cell lines derived from the nervous system used to study its effects, such as SH-SY5Y cells, BV-2 cells, N2a cells, etc. [19,39]. In vitro cellular models are easier to use than in vivo experimental models [40]. In addition, studies performed using cells are very reproducible and reliable, whilst being time-saving and cost-effective, and provide a bettercontrolled setting. In this regard, primary neuronal cultures and neuronal cell lines derived from rodents represent a useful tool to study the potential neurotoxicity of chemicals [41]. Moreover, primary neuronal cell cultures can provide a more similar phenotype to the real situation than immortal cell lines since these may acquire genetic instability during long times of passage, and neurites may not represent true axons or dendrites [41]. Specifically, the hippocampus is an area of the brain that possesses remarkable neuronal activity, and it is characterized by changes in synaptic responsiveness [42]. Recently, primary cultures of this brain area have been used to investigate aspects related to neurodegenerative diseases, such as the effect produced by toxic aggregates of alpha-synuclein [41], the antioxidant and neuroprotective effects of zolpidem [43], or the protective effects of cannabinoid receptor 2 agonist compounds against neuronal toxicity induced by the accumulation of beta-amyloid peptides [44]. In all of these studies, E17 embryonic murine primary hippocampal neuronal culture was selected in order to study the effects of CYN in neurons that are more similar to human neurons. In this regard, the markers NeuN and MAP-2 were used to measure cytotoxicity and also to confirm their maturity and neuronal nature; these markers are employed in the study of different neurodegenerative diseases, such as Parkinson's or Alzheimer's [45,46].

Taking these facts into account, CYN was demonstrated, for the first time, to cause a concentration- and time-dependent decrease in viability in a range of $0-1 \mu \mathrm{g} / \mathrm{mL}$ after 24 and $48 \mathrm{~h}$ of exposure in our experiment, causing significant changes compared to the respective negative control group. At the lowest concentrations tested in our experimental model $(0.25$ and $0.5 \mu \mathrm{g} / \mathrm{mL})$, cytotoxicity was only observed after $48 \mathrm{~h}$ of exposure. However, the highest CYN concentration $(1 \mu \mathrm{g} / \mathrm{mL})$ was demonstrated to cause a significant decrease in neuronal viability after 24 and $48 \mathrm{~h}$. This finding is important, as the concentration range used in this study has been naturally found in environmental samples [7]. This is the first study to use neuron-specific biomarkers such as NeuN and MAP2 to assess CYN cytotoxicity. These results are in agreement with those obtained by Hinojosa et al. [31] in the undifferentiated human neuroblastoma cell line SH-SY5Y, where the EC50 reported was around $1 \mu \mathrm{g} / \mathrm{mL}$ after $24 \mathrm{~h}$. However, when the same authors studied its effects on differentiated SH-SY5Y cells, which are supposed to be more similar to primary cultures, the EC50 value obtained after $24 \mathrm{~h}$ of exposure was $0.3 \mu \mathrm{g} / \mathrm{mL}$, with these cells being the most sensitive to the cyanotoxin. This might be due to differences between the biomarkers used to measure cytotoxicity in the two studies: the MTS assay in Hinojosa et al. [31] compared to NeuN and MAP2 biomarkers in the present work. Thus, the EC50 values were higher when these authors studied viability by performing the neutral red uptake assay or the protein content assay, demonstrating the sensitivity of the assay to those experimental conditions.

Nonetheless, in the present study, viability was studied by using specific biomarkers from mature neurons that are supposed to be present in primary neuronal cultures in order to not only assess the effects of the cyanotoxin on the cell viability but also confirm that our culture contains mainly neurons after isolation from the hippocampus [47]. The concentration- and time-dependent decrease observed in the present study is also in agreement with the results presented by Takser et al. [48], who exposed N2a murine neuroblastoma-derived cells and BV-2 microglia murine cells to 0.1 and $10 \mu \mathrm{M} \mathrm{CYN}$ and observed a significant decrease in cell viability after exposure for 24,48 , and $72 \mathrm{~h}$ to both concentrations. Although they just studied two concentrations, and thus, it is difficult to compare the responses to the ones obtained in our study, the BV-2 cells were demonstrated to be the most sensitive cell line in their study, showing more significant changes after both times of exposure. This demonstrates that the behavior of the cells can differ according 
to the experimental model, but a concentration- and time-dependent trend was observed in all of them. In addition, both Takser et al. [48] and Hinojosa et al. [31] demonstrated apoptosis in their respective cell models.

Concerning neurofunctional studies, in our model, the markers synaptophysin and PSD95 were employed to study the number of synapses through their colocalization. These markers are usually employed to study the effects of a toxin during synaptic development or to study synaptogenesis during development [46,49]. In this study, CYN caused significant decreases in these synaptic markers after exposure to $0.5 \mu \mathrm{g} \mathrm{CYN} / \mathrm{mL}$ for $12 \mathrm{~h}$ in our experimental model and after exposure to $1 \mu \mathrm{g} C Y N / m L$ for both exposure times. To our knowledge, this is the first study focused on synaptic response disruption caused by CYN. The only reports studying the effects of CYN on synaptic function have been carried out indirectly by studying acetylcholinesterase activity (AChE), as a decrease in this enzyme would lead to an overstimulation of postsynaptic neurons and, thus, lead to cholinergic disturbances. In this regard, the only study performed in vitro was the one carried out by Hinojosa et al. [31], who observed no alteration in undifferentiated SH-SY5Y cells after exposure to $0-1 \mu \mathrm{g} / \mathrm{mL}$ CYN for $24 \mathrm{~h}$, while in differentiated cells, 0.15 and $0.3 \mu \mathrm{g} / \mathrm{mL}$ caused a decrease in this enzymatic activity. This is in agreement with our results, as the present study also demonstrated a significant decrease in synaptic integrity after $12 \mathrm{~h}$ of exposure. The disruption of normal synaptic formation and function is often seen as an endpoint in neurological diseases. Moreover, the ability to quantify changes in structural synaptic formation after treatment with a toxicant may not only provide much-needed information about the extent of the effect but may also provide clues to the underlying mechanisms [42]. It is also worth mentioning that CYN also caused a decrease in AChE in vivo in tilapia fish exposed to a CYN-producing strain of C. ovalisporum for 14 days [22]. The decrease in AChE could be due to a link between CYN and AChE, which would lead to the accumulation of $\mathrm{ACh}$ in the receptors and, thus, overstimulation, which is in agreement with the results obtained in our study. In this regard, as observed in Figure 5, the number of presynaptic markers did not vary after exposure to CYN, while the quantity of the red signal decreased in our study. Taking into account that PSD95 is present in postsynaptic excitatory neurons, the overstimulation of those neurons by the lack of AChE would lead to a decrease in this signal, decreasing synaptogenesis. This decrease could result in the generation of neurodegenerative diseases or problems during neurodevelopment in the case of exposure during pregnancy [50]. In addition, it is important to take into account that the primary cultures were obtained from the hippocampus; a lack of synapsis at this level would lead to learning and memory impairment, together with changes in spatial navigation, emotional behavior, and regulation of hypothalamic functions [51].
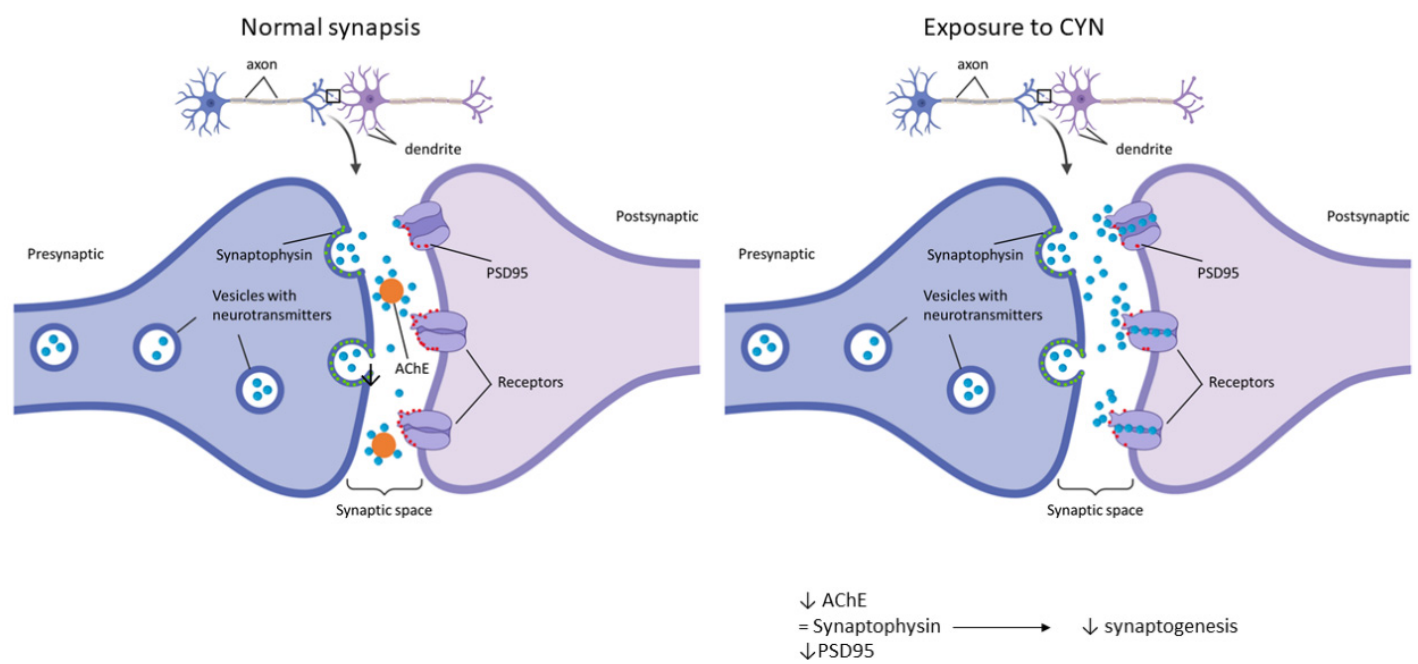

Figure 5. Schematic diagram of normal synapsis vs. synapsis after exposure to CYN. 
The toxicity profile of CYN partially resembles that of microcystins in the sense that both of them are primarily hepatotoxic, but they have been reported to also induce potential neurotoxic effects [19]. Thus, the neurotoxicity of cyanotoxins in general and of CYN in particular is worthy of research and requires further attention. In this regard, the use of novel and advanced experimental models such as primary neuronal cultures could contribute to the progress of scientific knowledge on this topic.

\section{Conclusions}

Our findings demonstrate that $\mathrm{CYN}$ is able to cause effects on murine primary cultures of neurons, causing a concentration- and time-dependent decrease in viability after exposure to environmentally relevant concentrations of the toxin. In addition, for the first time, it is shown that CYN is able to cause a concentration-dependent decrease in the synaptic number. Thus, these results highlight the importance of carrying out more experiments concerning the neurotoxic properties that CYN can exert in order to properly evaluate its risk and its possible implication in neurodegenerative diseases.

\section{Materials and Methods}

\subsection{Materials}

Cylindrospermopsin (purity $>95 \%$ by HPLC) was purchased from Enzo Life Sciences (Barcelona, Spain). Dako Fluoromount ${ }^{\mathrm{TM}}$ aqueous mounting (F4680), glucose (2.5 M) (68769), HEPES (68769), HBSS 10× (H9269), L-cysteine (C7352-256), poly-D-lysine (P6407), Triton $^{\mathrm{TM}}$ X-100 solution (93443), and trypsin inhibitor (T9128) were purchased from Sigma Aldrich (Madrid, Spain). PBS 10× (X0515-500), penicillin + streptomycin 100× (L0022100), DMEM-F12 (L0090-500), glutamine (Q) 100× (X0550-100), and horse serum (5091H500) were obtained from Biowest (Barcelona, Spain). Sodium pyruvate (11360-070), neurobasal (21103-049), B27 supplement 50× (17504-044), and Glutamax (35050061) were purchased from Gibco (Madrid, Spain). Papain (LS003127) was purchased from Worthington (Barcelona, Spain). Ethanol absolute (20821.330) was purchased from VWR Chemicals (Madrid, Spain). Paraformaldehyde 4\% (15434389) was purchased from Alfa Aesar $^{\mathrm{TM}}$ (Madrid, Spain). The antibodies anti-microtubule-associated protein 2 (MAP2) (AB5622), anti-postsynaptic density protein 95 (PSD95) (MAB 1596), and anti-NeuN clone A60 (NeuN) (MAB377) were obtained from EDM Millipore Corp (Darmstadt, Germany). Synaptophysin 1 (101002) was purchased from Synaptic Systems (Goettingen, Germany). Secondary antibodies Alexa Fluor ${ }^{\mathrm{TM}} 546$ donkey anti-rabbit IgG (H+L) (A10040) and Alexa Fluor $^{\mathrm{TM}} 488$ donkey anti-mouse IgG (H+L) (A21202) were purchased from Invitrogen by Thermo Fisher Scientific (Madrid, Spain).

\subsection{Toxin Test Solution}

A stock solution of $1 \mathrm{mg} / \mathrm{mL}$ CYN was prepared in sterilized Milli-Q water and maintained at $-20{ }^{\circ} \mathrm{C}$ until its use.

\subsection{Animals}

Pregnant mice (CD1) at 17 days of gestation were used to obtain hippocampal neurons. All animals received human care in accordance with the directive for the protection of animals utilized for scientific purposes: Directive 2010/63/UE, Decision 2020/569/UE, and RD 1386/2018. All methods were authorized by the Ethical Animal Experimentation Committee of the University of Sevilla and by the Junta de Andalucía (project no. 04/03/2019/020).

\subsection{Primary Culture of Hippocampal Neurons and Toxin Exposure}

Primary cultures were obtained from the hippocampus of E17 embryonic CD1 mice according to the protocol described by Zhao et al. [39]. Briefly, the hippocampus was isolated in cold dissociation medium with HBSS, glucose $(10 \mathrm{mM})$, and HEPES (10 mM). Afterwards, they were incubated for 3 min at $37^{\circ} \mathrm{C}$ with slow agitation in a solution of 
papain $(41 \mathrm{U} / \mathrm{mL})$ and L-cysteine $0.06 \%(\mathrm{p} / \mathrm{v})$ in dissociation medium. Then, the samples were washed 3 times with trypsin inhibitor $(1 \mathrm{mg} / \mathrm{mL})$ in dissociation medium and then incubated again for $4 \mathrm{~min}$ at $37^{\circ} \mathrm{C}$ with slow agitation. After that, the hippocampi were mechanically disaggregated in the presence of medium containing DMEM-F12 supplemented with glutamine $(2 \mathrm{mM})$, sodium pyruvate $(1 \%)$, glucose $(20 \mathrm{mM})$, and inactivated horse serum (10\%). Then, 80,000 cells/well were seeded in coverslips in 24-well plates previously coated with poly-D-lysine. After $2 \mathrm{~h}$, the medium was replaced by neuronal medium containing neurobasal, B27 $(2 \%)$, Glutamax $(2 \mathrm{mM})$, and penicillin and streptomycin $(50 \mu \mathrm{g} / \mathrm{mL})$. One-quarter of the medium was refreshed every 2-3 days. After 21 days, the neurons were exposed to $0.25,0.5$, and $1 \mu \mathrm{g} / \mathrm{mLCYN}$ for 12,24 , and $48 \mathrm{~h}$. These experimental concentrations were selected to encompass the range of environmentally relevant concentrations found in nature (up to $1 \mu \mathrm{g} / \mathrm{mL}$ ).

\subsection{Sample Fixation and Immunocytochemistry}

The cells were fixed with paraformaldehyde (4\%) for $20 \mathrm{~min}$ at room temperature. Then, PBS was used to wash the samples twice, and ethanol (70\%) was added for maintenance at $4{ }^{\circ} \mathrm{C}$ until the performance of the immunocytochemical analysis. After PBS washing, the cells were incubated with $0.1 \%$ Triton-X 100 in PBS for $1 \mathrm{~h}$ at room temperature to permeabilize. Then, samples were incubated with blocking solution $(0.1 \%$ Triton- $X$ 100 and $1 \%$ bovine serum albumin (BSA) in PBS) for $3 \mathrm{~h}$. After that, primary antibodies (NeuN 1:1000 and MAP2 1:1000, or synaptophysin 1 1:500 and PSD95 1:100) were added to a solution with $0.1 \%$ Triton-X 100 and $1 \%$ BSA, which was left at room temperature for 30 min and then incubated at $4{ }^{\circ} \mathrm{C}$ overnight, except for PSD95, which required incubation for 3 days. Finally, samples were washed with $0.1 \%$ Triton-X 100 in PBS and incubated with 1:500 dilution of the secondary antibodies (Alexa Fluor ${ }^{\mathrm{TM}} 546$ donkey anti-rabbit IgG and 488 donkey anti-mouse IgG) in PBS with $0.1 \%$ Triton-X 100 and $1 \%$ BSA for an hour. Finally, the samples were washed twice with PBS, and the coverslips were added to the slides with Fluorescent Mounting Medium.

\subsection{Image Acquisition and Analysis}

The images were obtained by Zeiss apotome epifluorescence microscope at $20 \times$ to capture viability images and ZEISS LSM 710 confocal microscope using a $63 \times$ oil-immersion objective lens to capture neuronal synapsis images. Then, they were analyzed using ImageJ (FIJI) and the plugins "Cell Counter" to quantify the number of neurons and "NeuronJ" and "SynaptCountJ" to quantify PSD95 and synaptophysin colocalization in neuronal synapses [52].

\subsection{Data Analysis}

Data are presented as mean \pm standard deviation (SD) in relation to control. Statistical analysis was carried out using analysis of variance (ANOVA), followed by Tukey's multiple comparison tests using GraphPad Prism 7.05.

Author Contributions: Conceptualization, J.V., A.M.C., Á.J.; Methodology, A.I.P., M.G.H., M.V.S.-M. and C.M.-C.; Software, M.G.H.; Validation, M.V.S.-M., C.M.-C. and A.I.P.; Formal Analysis, M.G.H. and A.I.P.; Investigation, A.I.P., M.G.H., C.M.-C. and M.V.S.-M.; Resources, Á.J. and A.M.C.; Data Curation, M.G.H. and A.I.P.; Writing-Original Draft Preparation, M.G.H. and A.I.P.; WritingReview \& Editing, A.I.P., M.V.S.-M., C.M.-C., J.V., Á.J. and A.M.C.; Visualization, A.I.P., M.G.H., M.V.S.-M., C.M.-C., J.V., Á.J. and A.M.C.; Supervision, J.V., A.M.C. and Á.J.; Project Administration, Á.J. and A.M.C.; Funding Acquisition, Á.J. and A.M.C. All authors have read and agreed to the published version of the manuscript.

Funding: This research was funded by the Ministerio de Economía y Competitividad of Spain (AGL2015-64558-R, MINECO/FEDER, UE) and Spanish Ministerio de Ciencia e Innovación (PID2019104890RB-I00 MICIN/ AEI /10.13039/501100011033). C.M.C. and M.S.M. were supported by PhD fellowships from FPU (Spanish Ministry of Science, Innovation and Universities). 
Institutional Review Board Statement: "The animal study protocol was approved by the Ethical Animal Experimentation Committee of the University of Sevilla and by the Junta de Andalucía (protocol code project no. 04/03/2019/020)."

Informed Consent Statement: Not applicable.

Acknowledgments: The authors wish to thank the Ministerio de Economía y Competitividad of Spain (AGL2015-64558-R, MINECO/FEDER, UE) and Spanish Ministerio de Ciencia e Innovación (PID2019-104890RB-I00 MICIN/ AEI /10.13039/501100011033) for the financial support, and the Cell Culture Service and Microscopy Service of Centro de Investigación, Tecnología e Innovación from Universidad de Sevilla (CITIUS), for providing technical assistance. C.M-C. and M.V.S-M. were supported by PhD fellowships from FPU (Spanish Ministry of Science, Innovation and Universities).

Conflicts of Interest: The authors declare no conflict of interest.

\section{References}

1. Guzmán-Guillén, R.; Prieto Ortega, A.I.; Moreno, I.; González, G.; Soria-Díaz, M.E.; Vasconcelos, V.; Cameán, A.M. Development and optimization of a method for the determination of Cylindrospermopsin production from strain of Aphanizomenon cultures: Intra-laboratory assessment of its accuracy by using validation standards. Talanta 2012, 100, 356-363. [CrossRef] [PubMed]

2. Kokociński, M.; Cameán, A.M.; Carmeli, S.; Guzmán-Guillén, R.; Jos, A.; Mankiewicz-Boczek, J.; Metcalf, J.S.; Moreno, I.M.; Prieto, A.I.; Sukenik, A. Cylindrospermopsin and Congeners. In Handbook of Cyanobacterial Monitoring and Cyanotoxin Analysis; Meriluoto, J., Spoof, L., Codd, G.A., Eds.; John Wiley \& Sons, Ltd.: Chichester, UK, 2017; pp. 127-137.

3. Ohtani, I.; Moore, R.E.; Runnegar, M.T.C. Cylindrospermopsin: A potent hepatotoxin from the blue-green alga Cylindrospermopsis raciborskii. J. Am. Chem. Soc. 1992, 114, 7941-7942. [CrossRef]

4. $\quad$ Chiswell, R.K.; Shaw, G.R.; Eaglesham, G.; Smith, M.J.; Norris, R.L.; Seawright, A.A.; Moore, M.R. Stability of cylindrospermopsin, the toxin from the cyanobacterium. Cylindrospermopsis raciborskii: Effect of $\mathrm{pH}$, temperature, and sunlight on decomposition. Environ. Toxicol. 1999, 14, 155-161.

5. Kinnear, S. Cylindrospermopsin: A decade of progress on bioaccumulation research. Mar. Drugs 2010, 8, 542-564. [CrossRef]

6. Buratti, F.M.; Manganelli, M.; Vichi, S.; Stefanelli, M.; Scardala, S.; Testai, E.; Funari, E. Cyanotoxins: Producing organisms, occurrence, toxicity, mechanism of action and human health toxicological risk evaluation. Arch. Toxicol. 2017, 91, 1049-1130. [CrossRef] [PubMed]

7. Yang, Y.; Yu, G.; Chen, Y.; Jia, N.; Li, R. Four decades of progress in cylindrospermopsin research: The ins and outs of a potent cyanotoxin. J. Hazard. Marter. 2021, 406, 124653. [CrossRef]

8. Otero, P.; Silva, M. Chapter 7-The role of toxins: Impact on human health and aquatic environments. In The Pharmacological Potential of Cyanobacteria; Lopes, G., Silva, M., Vasconcelos, V., Eds.; Elsevier: Amsterdam, The Netherlands, 2022 ; pp. 173-199.

9. Mutoti, M.; Gumbo, J.; Jideani, A.I.O. Occurrence of cyanobacteria in water used for food production: A review. Phys. Chem. Earth Parts A/B/C 2022, 125, 103101. [CrossRef]

10. Ríos, V.; Moreno, I.; Prieto, A.I.; Puerto, M.; Gutiérrez-Praena, D.; Soria, M.E.; Cameán, A.M. Analysis of MC-LR and MCRR in tissue from freshwater fish (Tinca tinca) and crayfish (Procambarus clarkii) in tench ponds (Cáceres, Spain) by Liquid Chromatography-Mass spectrometry (LC-MS). Food Chem. Toxicol. 2013, 57, 170-178. [CrossRef]

11. Guzmán-Guillen, R.; Moreno, I.; Prieto, A.I.; Soria-Diaz, M.E.; Vasconcelos, V.M.; Cameán, A.M. CYN determination in tissues from freshwater fish by LC-MS/MS: Validation and application in tissues form subchronically exposed tilapia (Oreochromis niloticus). Talanta 2015, 131, 452-459. [CrossRef]

12. Gutiérrez-Praena, D.; Jos, Á.; Pichardo, S.; Moreno, I.M.; Cameán, A.M. Presence and bioaccumulation of microcystins and cylindrospermopsin in food and the effectiveness of some cooking techniques at decreasing their concentrations: A review. Food Chem. Toxicol. 2013, 53, 139-152. [CrossRef]

13. Codd, G.A.; Meriluoto, J.; Metcalf, J.S. Introduction: Cyanobacteria, cyanotoxins, their human impact, and risk management. In Handbook of Cyanobacterial Monitoring and Cyanotoxin Analysis; John Wiley \& Sons, Ltd.: Chichester, UK, 2017; pp. 3-8.

14. Byth, S. Palm Island mystery disease. Med. J. Aust. 1980, 2, 40-42. [CrossRef] [PubMed]

15. Carmichael, W.W.; Azevedo, S.M.; An, J.S.; Molica, R.J.; Jochimsen, E.M.; Lau, S.; Rinehart, K.L.; Shaw, G.R.; Eaglesham, G.K. Human fatalities from cyanobacteria: Chemical and biological evidence for cyanotoxins. Environ. Health Perspect. 2001, 109, 663-668. [CrossRef] [PubMed]

16. Gutiérrez-Praena, D.; Pichardo, S.; Jos, Á.; Moreno, J.; Cameán, A.M. Alterations observed in the endothelial HUVEC cell line exposed to pure Cylindrospermopsin. Chemosphere 2012, 89, 1151-1160. [CrossRef] [PubMed]

17. Pichardo, S.; Cameán, A.M.; Jos, A. In vitro toxicological assessment of cylindropermopsin: A review. Toxins 2017, 9, 402. [CrossRef] [PubMed]

18. Pichardo, S.; Devesa, V.; Puerto, M.; Vélez, D.; Cameán, A.M. Intestinal transport of Cylindrospermopsin using the Caco-2 cell line. Toxicol. In Vitro 2017, 38, 142-149. [CrossRef]

19. Hinojosa, M.G.; Gutiérrez-Praena, D.; Prieto, A.I.; Guzmán-Guillén, R.; Jos, A.; Cameán, A.M. Neurotoxicity induced by microcystins and cylindrospermopsin: A review. Sci. Total Environ. 2019, 668, 547-565. [CrossRef] [PubMed] 
20. Terao, K.; Ohmori, S.; Igarashi, K.; Ohtani, I.; Watanabe, M.F.; Harada, K.I.; Ito, E.; Watanabe, M. Electron-microscopic studies on experimental poisoning in mice induced by cylindrospermopsin isolated from blue-green-alga Umezakia Natans. Toxicon 1994, 32, 833-843. [CrossRef]

21. Guzmán-Guillén, R.; Prieto Ortega, A.I.; Moreno, I.M.; Ríos, V.; Moyano, R.; Blanco, A.; Vasconcelos, V.; Cameán, A.M. Effects of Depuration on Histopathological Changes in Tilapia (Oreochromis Niloticus) After Exposure to Cylindrospermopsin. Environmental Toxicology 2016, 1318-1332. [CrossRef]

22. Guzmán-Guillén, R.; Lomares, I.; Moreno, I.M.; Prieto, A.I.; Moyano, R.; Blanco, A.; Cameán, A.M. Cylindrospermopsin induces neurotoxicity in tilapia fish (Oreochromis niloticus) exposed to Aphanizomenon ovalisporum. Aquat. Toxicol. 2015, 161, 17-24. [CrossRef]

23. Da Silva, R.C.; Grötzner, S.R.; Moura Costa, D.D.; Esquivel, J.R.; Muelbert, J.; Freitas de Magalhães, V.; Filipak, F.; De Oliveira, C.A. Comparative bioaccumulation and effects of purified and cellular extract of cylindrospermopsin to freshwater fish Hoplias malabaricus. J. Toxicol. Environ. Health Part A Curr. Issues 2018, 81, 620-632. [CrossRef]

24. Rabelo, J.C.S.; Hanusch, A.L.; De Jesus, L.W.O.; Mesquita, L.A.; Franco, F.C.; Silva, R.A.; Sabóia-Morais, S.M.T. DNA damage induced by cylindrospermopsin on different tissues of the biomonitor fish Poecilia reticulate. Environ. Toxicol. 2021, 36, 1125-1134. [CrossRef] [PubMed]

25. Chernoff, N.; Hill, D.J.; Chorus, I.; Diggs, D.L.; Huang, H.; King, D.; Lang, J.R.; Le, T.-T.; Schmid, J.E.; Travlos, G.S.; et al. Cylindrospermopsin toxicity in mice following a 90-d oral exposure. J. Toxicol. Environ. Health Part A 2018, 81, 549-566. [CrossRef] [PubMed]

26. Díez-Quijada, L.; Moyano, R.; Molina-Hernández, V.; Cameán, A.M.; Jos, A. Evaluation of toxic effects induced by repeated exposure to Cylindrospermopsin in rats using a 28-day feeding study. Food Chem. Toxicol. 2021, 151, 112108. [CrossRef]

27. Poniedziałek, B.; Rzymski, P.; Kokociński, M. Cylindrospermopsin: Water-linked potential threat to human health in Europe. Environ. Toxicol. Pharm. 2012, 34, 651-660. [CrossRef] [PubMed]

28. Poniedziałek, B.; Rzymski, P.; Kokociński, M.; Karczewski, J. Toxic potencies of metabolite(s) of non-cylindrospermopsin producing Cylindrospermopsis raciborskii isolated from temperate zone in human white cells. Chemosphere 2015, 120, 608-614. [CrossRef] [PubMed]

29. Puerto, M.; Pichardo, S.; Jos, Á.; Gutiérrez-Praena, D.; Cameán, A.M. Acute effects of pure Cylindrospermopsin on the activity and transcription of antioxidant enzymes in Tilapia (Oreochromis niloticus) exposed by gavage. Ecotoxicology 2011, 20, 1852-1860. [CrossRef] [PubMed]

30. Žegura, B.; Gajski, G.; Štraser, A.; Garaj-Vrhovac, V. Cylindrospermopsin induced DNA damage and alteration in the expression of genes involved in the response to DNA damage, apoptosis and oxidative stress. Toxicon 2011, 58, 471-479. [CrossRef]

31. Hinojosa, M.G.; Prieto, A.I.; Gutiérrez-Praena, D.; Moreno, F.J.; Cameán, A.M.; Jos, A. Neurotoxic assessment of microcystin-LR, cylindrospermopsin and their combination on the human neuroblastoma SH-SY5Y cell line. Chemosphere 2019, 224, 751-764. [CrossRef]

32. Gusel'nikova, V.V.; Korzhevskiy, D.E. NeuN as a neuronal nuclear antigen and neuron differentiation marker. Acta Nat. 2015, 7, 42-47. [CrossRef]

33. Johnson, G.V.W.; Jope, R.S. The role of microtubule-associated protein 2 (MAP-2) in neuronal growth, plasticity, and degeneration. J. Neurosci. Res. 1992, 33, 505-512. [CrossRef]

34. Soltani, M.H.; Pichardo, R.; Song, Z.; Sangha, N.; Camacho, F.; Satyamoorthy, K.; Sangueza, O.P.; Setaluri, V. Microtubuleassociated protein 2, a marker of neuronal differentiation, induces mitotic defects, inhibits growth of melanoma cells, and predicts metastatic potential of cutaneous melanoma. Am. J. Pathol. 2005, 166, 1841-1850. [CrossRef]

35. Phelan, P.; Gordon-Weeks, P.R. Widespread Distribution of Synaptophysin, a Synaptic Vesicle Glycoprotein, in Growing Neurites and Growth Cones. Eur. J. Neurosci. 1992, 4, 1180-1190. [CrossRef] [PubMed]

36. Béique, J.C.; Andrade, R. PSD-95 regulates synaptic transmission and plasticity in rat cerebral cortex. J. Physiol. 2003, 546, 859-867. [CrossRef]

37. Ayeni, E.A.; Gong, Y.; Yuan, H.; Hu, Y.; Bai, X.; Liao, X. Medicinal plants for anti-neurodegenerative diseases in West Africa. J. Ethnopharmacol. 2021, 11, 114468. [CrossRef] [PubMed]

38. Bondy, S.C. Anthropogenic pollutants may increase the incidence of neurodegenerative disease in an aging population. Toxicology 2016, 3, 41-46. [CrossRef]

39. Hinojosa, M.G.; Prieto, A.I.; Gutiérrez-Praena, D.; Moreno, F.J.; Cameán, A.M.; Jos, A. In vitro assessment of the combination of cylindrospermopsin and the organophosphate chlorpyrifos on the human neuroblastoma SH-SY5Y cell line. Ecotoxcol. Environm Saf. 2020, 191, 110222. [CrossRef] [PubMed]

40. Constantinescu, R.; Constantinescu, A.T.; Reichmann, H.; Janetzky, B. Neuronal differentiation and long-term culture of the human neuroblastoma line SH-SY5Y. J. Neural Transm. Suppl. 2007, 72, 17-28.

41. Heravi, M.; Dargahi, L.; Parsafar, S.; Tayaranian Marvian, A.; Aliakbari, F.; Morshedi, D. The primary neuronal cells are more resistant than PC12 cells to $\alpha$-synuclein toxic aggregates. Neurosci. Lett. 2019, 14, 38-47. [CrossRef] [PubMed]

42. Giordano, G.; Costa, L.G. Primary neurons in culture and neuronal cell lines for in vitro neurotoxicological studies. Methods Mol. Biol. 2011, 758, 13-27. [PubMed]

43. Yousefsani, B.S.; Akbarizadeh, N.; Pourahmad, J. The antioxidant and neuroprotective effects of Zolpidem on acrylamide-induced neurotoxicity using Wistar rat primary neuronal cortical culture. Toxicol. Rep. 2020, 7, 233-240. [CrossRef] [PubMed] 
44. Zhao, W.Q.; De Felice, F.G.; Fernandez, S.; Chen, H.; Lambert, M.P.; Quon, M.J.; Krafft, G.A.; Klein, W.L. Amyloid beta oligomers induce impairment of neuronal insulin receptors. FASEB J. 2008, 22, 246-260. [CrossRef]

45. Cossette, M.; Lévesque, D.; Parent, A. Neurochemical characterization of dopaminergic neurons in human striatum. Parkinsonism Relat. Disord. 2005, 11, 277-286. [CrossRef] [PubMed]

46. Sánchez-Varo, R.; Trujillo-Estrada, L.; Sánchez-Mejias, E.; Torres, M.; Baglietto-Vargas, D.; Moreno-González, I.; De Castro, V.; Jiménez, S.; Ruano, D.; Vizuete, M.; et al. Abnormal accumulation of autophagic vesicles correlates with axonal and synaptic pathology in young Alzheimer's mice hippocampus. Acta Neuropathol. 2012, 123, 53-70. [CrossRef] [PubMed]

47. Todd, S.W. Effects of Continuous Exposure of SH-SY5Y Neuroblastoma Cells to Chlorpyrifos on Neuronal Differentiation: Implications for Neurotoxicity. Ph.D. Dissertation, Faculty of the Graduate School of the University of Maryland, Baltimore, MD, USA, 2017.

48. Takser, L.; Benachour, N.; Husk, B.; Cabana, H.; Gris, D. Cyanotoxins at low doses induce apoptosis and inflammatory effects in murine brain cells: Potential implications for neurodegenerative diseases. Toxicol. Rep. 2016, 3, 180-189. [CrossRef] [PubMed]

49. Glantz, L.A.; Gilmore, J.H.; Hamer, R.M.; Lieberman, J.A.; Jarskog, L.F. Synaptophysin and postsynaptic density protein 95 in the human prefrontal cortex from mid-gestation into early adulthood. Neuroscience 2007, 149, 582-591. [CrossRef] [PubMed]

50. Liu, B.; Kou, J.; Li, F.; Huo, D.; Xu, J.; Zhou, X.; Meng, D.; Ghulam, M.; Artyom, B.; Gao, X.; et al. Lemon essential oil ameliorates age-associated cognitive dysfunction via modulating hippocampal synaptic density and inhibiting acetylcholinesterase. Aging 2020, 12, 8622-8639. [CrossRef] [PubMed]

51. Anand, K.S.; Dhikav, V. Hippocampus in health and disease: An overview. Ann. Indian Acad. Neurol. 2012, 15, $239-246$.

52. Mata, G.; Cuesto, G.; Heras, J.; Morales, M.; Romero, A.; Rubio, J. SynapCountJ: A Validated Tool for Analyzing Synaptic Densities in Neurons. In Biomedical Engineering Systems and Technologies; BIOSTEC 2016; Communications in Computer and Information Science; Fred, A., Gamboa, H., Eds.; Springer: Cham, Switzerland, 2017; Volume 690, pp. 41-55. 